\title{
Invited In but Kept Out: Experiences of Skilled Afrikaans-Speaking South African Immigrants in Australia
}

\author{
HannaJagtenberg
}

\begin{abstract}
Based on ongoing fieldwork amongst white Afrikaans-speaking South African immigrants in Australia, in this chapter I argue that Australia's immigration policy contradicts everyday reality. The country actively recruits skilled South Africans, many of whom are Afrikaners/Afrikaans. Because they receive visas based on their qualifications and experience, they expect to find employment in Australia easily. Once arrived, however, they find that many Australians view them as foreigners who have come to steal their jobs. Consequently, they struggle to find employment and/or to advance their career. Underneath this problem lie the misleading perceptions that white-onwhite migration is easy and that 'Western' cultures are similar, which contribute to false expectations. Thus, it appears that, in addition to their post-apartheid identity struggle in and alienation from their home country, the Afrikaners/Afrikaans people in Australia are now struggling to give meaning to their lives in a, for them, strange and often unwelcoming land.
\end{abstract}

\section{Keywords}

Australia - South Africa - Afrikaners/Afrikaans people - skilled migration - white privilege - discrimination - false expectations - cultural differences - identity struggle

Since the mid-199os, Australia attracts a steady flow of skilled South African immigrants, many of whom belong to the 'white,', or Caucasian,

1 Strictly speaking, skin colour is a physical attribute, not a state of being. However, in our racialised world, labels for skin colour are often used in the latter sense, i.e. as if people are 
Afrikaans-speaking subgroup generally still known as 'Afrikaners', though increasingly as 'Afrikaans.' Although the exact figure is difficult to determine, based on available data ${ }^{3}$ I would argue that at least half of the 145,683 South Africans in Australia counted in the 2011 Census is Afrikaans, which means that this ethnocultural subgroup accounts for approximately o,5 per cent of the Australian population, and the number continues to increase. ${ }^{4}$ In light of this interesting phenomenon, I am currently conducting an ethnographic study on Afrikaans immigrant experiences in Australia for my doctoral degree at the University of Adelaide. ${ }^{5}$ This chapter is thus based on empirical research. The data is collected through informal, semi-structured interviews, casual conversations, participant observation and the analysis of texts, mainly Facebook group discussions. Fieldwork has been conducted since September 2015 and will continue until the end of 2016. Thus far, approximately 130 people have participated in the research, 70 of whom through interviews. The research sample is drawn from those Afrikaans people that emigrated as adults (i.e. the first generation) between 1994 and today and is mainly selected through snowball sampling. The majority has emigrated as a nuclear family unit, and the average age of participants is between thirty and fifty years. The main fieldwork location is Adelaide/South Australia, though interviews have also been conducted in Sydney and Melbourne and will be conducted in Perth as well.

indeed their skin. As such, the term 'white' has become a signifier of many other attributes, for example, 'powerful', 'wealthy', and 'privileged' amongst others. Although I follow the common usage of the concept, I have put it in quotation marks here, since I agree with Jon Stratton that it is, 'like all forms of racialised classifications [...] a discursive construction' Jon Stratton, Uncertain Lives: Culture, Race and Neoliberalism in Australia (Newcastle upon Tyne: Cambridge Scholars Publishing, 2011), 4.

2 My fieldwork observations lead me to conclude that the majority of Afrikaners prefers to be referred to as 'Afrikaans' nowadays, since they feel that the former name is associated with the apartheid regime. Respecting this, I use the new term throughout this chapter.

3 This calculation is based on the following three main sources: 'Mid-Year Population Estimates 2011', Statistics South Africa, viewed 7 March 2012, http://www.statssa.gov.za/publications/ Po302/Po3022011.pdf; Hermann Giliomee, The Afrikaners: Biography of a People (London: Hurst \& Company, 2011), 700-709; and Elirea Bornman, 'Emigrasie onder Afrikaners vandag', Tydskrif vir Geesteswetenskappe 45·3 (2005): 386-399.

4 Other sources used are: Anikó Hatoss, Donna Starks and Henriette Janse van Rensburg, 'Afrikaans Language Maintenance in Australia', Australian Review of Applied Linguistics 34.1 (2011): 4-23; David Lucas, Acheampong Yaw Amoateng and Ishmael Kalule-Sabiti, 'International Migration and the Rainbow Nation', Population, Space and Place 12 (2006): 45-63; and Johann van Rooyen, The New Great Trek: The Story of South Africa's White Exodus (Pretoria: Unisa Press, 2000).

5 The research underlying this paper is being conducted with support of an Australian Government Research Training Program Scholarship. 
Nearly all Afrikaans people that have participated in the research project thus far have left their home country primarily because they do not see a future for their children and, to a lesser extent, for themselves, in South Africa, due to their skin colour. The dominant perception is that, due to the majority African National Congress (ANC) government's post-1994 economic policies aimed at redressing apartheid's injustices, South Africa now knows 'reverse apartheid', meaning that white South Africans, and Afrikaans people in particular, are being discriminated against in the sense that they do not have equal access to education and jobs. Because of this, many interviewees ${ }^{6}$ see themselves as (albeit privileged) political refugees who are no longer welcome in their home country. The main reason why they choose Australia as their destination country is because they perceive the transfer from South Africa's to Australia's job market to be relatively easy and because the two countries are viewed as culturally and geographically similar. ${ }^{7}$

These perceptions are mainly derived from the fact that the Australian government has increasingly focused on attracting skilled migrants since the mid-199os, ${ }^{8}$ and from stories participants heard from immigration agents at recruiting events in South Africa. Under Australia's State Specific and Regional Migration Schemes set up during the 199os, various states have been very active and successful with specific recruitment programs (e.g. 'ImmigrationSA' in South Australia). ${ }^{9}$ In collaboration with Australian or multinational companies, immigration agents and other organisations with a vested interest, Australian state governments organise information days or evenings, so-called ' $\mathrm{Ex}$ po's', in major cities in South Africa, aimed at recruiting skilled migrants. Many

6 I am aware of the tendency among contemporary social scientists to speak of 'interlocutors' when referring to research participants, however, I choose to maintain the term 'interviewees', since I agree with Joost Beuving and Geert de Vries that the relationship between researcher and interviewee/informant is not an equal (reciprocal) one, i.e. '[the term interlocutor] disregards that we as researchers want to find out about society, and not the other way around' Joost Beuving and Geert de Vries, Doing Qualitative Research: The Craft of Naturalistic Inquiry (Amsterdam: Amsterdam University Press, 2015), 45.

7 See also Eric Louw and Gary Mersham, 'Packing for Perth: The Growth of a Southern African Diaspora', Asian and Pacific Migration Journal 10.2 (2001): 303-333; Van Rooyen, New Great Trek; Bruce Visser, 'From "Braai" to Barbecue: South African Immigration to Australia' (PhD diss., Flinders University, 2004).

8 Graeme Hugo, 'Change and Continuity in Australian International Migration Policy', International Migration Review 48.3 (2014): 868-89o; Winnifred R. Louis, et al., 'Speaking Out on Immigration Policy in Australia: Identity Threat and the Interplay of Own Opinion and Public Opinion', Journal of Social Issues 66.4 (2010): 653-672; Visser, “Braai” to Barbecue'.

9 'Immigration South Australia', Government of South Australia, Viewed 10 April 2016, http:// www.migration.sa.gov.au/. 
interviewees have attended such an 'Expo' before deciding to move to Australia. Most of them have subsequently entered the country on a Permanent Residency (PR) visa (subclass 190), which they were granted because Australia, or one specific state, had a shortage of people in their profession at that time (i.e. their occupation was on the 'Skilled Occupation List', more commonly known as the 'skills list'). ${ }^{10}$ The second major group was granted a Temporary Skilled (Worker) visa (subclass 457), which is an employer-sponsored visa for a period of up to four years. ${ }^{11}$ During this time, this group applied for PR too, as it presents the pathway to citizenship.

According to most research participants, at the 'Expo's', Australia is presented as the land of milk and honey, i.e. a place where everything is wonderful and perfect (at least for skilled and white-skinned South Africans) ${ }^{12}$ because they will get a job in no time and will easily adjust into Australian society, since the cultures are so similar. However, in their experienced reality, neither of these things is true. In the words of Carolien:

I think, with the immigration, there's a lot of deceit. Many lies are being told to the people, because they send the immigration agents out, and they offer a night, they say: "Do you want to emigrate? Come and listen to so and so $[\ldots]$ ", and they guarantee it will be successful. And then they have all these things that they tell you, amongst others the one thing that South Africans are doing really well here, that South Africans are very much sought-after here, that they get jobs very easily, that their children are doing very well at school, all those things they say. And the people believe this. ${ }^{13}$

10 'Skilled Nominated Visa', Australian Government, Viewed 14 May 2016, https://www .border.gov.au/Trav/Visa-1/19o-.

11 'Temporary Work (Skilled) Visa (Subclass 457)', Australian Government, Viewed 14 May 2016, https://www.border.gov.au/Trav/Visa-1/457-.

12 Australia has a long history of racial discrimination regarding (prospective) immigrants, epitomised by its 'White Australia Policy' (1901-1972) that denied access to anyone regarded as 'non-white', and is extremely restrictive towards non-skilled migrants and asylum seekers/refugees. See, for example, Louis, et al., 'Speaking Out'; John Pilger, A Secret Country: The Hidden Australia (New York: Alfred A. Knopf, Inc., 1991); Stratton, Uncertain Lives.

13 Carolien Jansen, interview with author, 2016. All citations from interviews in this chapter are my own translations from Afrikaans to English. To protect the identity of research 
Another participant, Adriaan, stated:

Whether it's the immigration agents or the big companies [...], they need people to work in inhabitable [...] places, and therefore come to recruit in South Africa. They offer less wages than they would offer Australians, but for a South African it's much more since he's used to getting paid in Rand. What they don't realise, is that life in Australia is also much more expensive than in South Africa, so that their salary isn't so much as it seems in relative terms. So either way, with the migration agents or with the big companies, South Africans are being cheated. It's not a land of milk and honey, Australia. ${ }^{14}$

One woman said that, coming back from 'such a visit' [Expo]

you almost have the idea that when you land here [in Australia] and you get off the plane, that the people will get you and put you in a car and, with a driver, drive you to an employment. And this is absolutely not how it is. ${ }^{15}$

Indeed, for many Afrikaans people reality is very different. Nearly all interviewees who entered Australia on PR visas without having secured a job beforehand struggled to get employment, specifically within their own profession. On average, it took them about two years and, for many, the job hunt took so long that they changed careers, usually entering into a lower economic sector (and thus class) than from which they came in South Africa: engineers became garbage collectors, lawyers became cleaners, consultants became security guards, managers became call centre operators. Those who did manage to get a job in their own field never started at their previous level: usually, they went two to three steps down the career ladder, which means that they lost five to ten years of working experience, like Paul for example, who had been working as a general manager in South Africa, and who only got a job as an operations manager in Australia. Many others had to do bridging courses or additional (university) course work and training in order to get their South African

participants, pseudonyms are used. Since there are relatively few Afrikaans names, I have chosen Dutch names as pseudonyms, to prevent Afrikaans people in Australia from being identified by mistake. Dutch and Afrikaans names are usually quite similar.

14 Adriaan van de Berg, conversation with author, 2016.

15 Catharina Jacobs, interview with author, 2016. 
qualifications certified in Australia. These extra trainings are usually expensive and time-consuming, causing people to rely heavily on their personal savings in their initial years in Australia, which places considerable financial strain on the families. In fact, this is one of the main reasons participants mentioned as to why some of their Afrikaans friends and acquaintances have returned to South Africa.

The perceived reason why Afrikaans people are struggling to get a job is that they are being discriminated against because of their immigrant status. Many research participants described Australians ${ }^{16}$ as very discriminatory, having a negative and closed attitude towards foreigners, and as being far more racist than South Africans ever were. ${ }^{17}$ In Adelaide in particular, Australian society is perceived as closed and cliquey, ruled by nepotism. The general feeling among Afrikaans people in Adelaide is that if you are not local, or if you do not know someone who is local, you will not get a (suitable) job. Some participants changed their surnames (to Australian/English ones) in order to be invited for job interviews; others deleted their South African experience from their résumés. Still, after that, they were rejected for not having local experience. Most participants feel, however, that the true reason for the rejection is being a foreigner. This sentiment is strengthened by the fact that frequently, after having gained the required local experience (often by working voluntarily for a number of months), they continue to be rejected, this time under the pretence that they are overqualified.

Indeed, Australians are thought to specifically dislike Afrikaans immigrants due to their relatively high qualifications. Perceivably, this makes Australians feel threatened and insecure, scared that these foreigners will bypass them or take their jobs. As a consequence of Australia's skill-based immigration policy, most contemporary immigrants, including the Afrikaans group, are in fact higher qualified than Australians. ${ }^{18}$ In addition to this, most non-British immigrants are by definition bi- or multilingual, which, according to the

16 With the term 'Australians', I refer to white-skinned descendants of Anglo-Celtic colonists, convicts and settlers. This is not because I do not acknowledge the existence of Aborigines or immigrant groups with Australian citizenship, but because this is the way in which my research participants, following mainstream Australian society, use the term.

17 This remark is usually made both with regards to Australia's genocidal history towards and continued oppression of Indigenous Australians, as well as to its contemporary treatment of immigrants and refugees/asylum seekers.

18 Lixin Cai and Amy Y.C. Liu, 'Wage Differentials between Immigrants and the Native-Born in Australia', International Journal of Manpower 36.3 (2015): 374-396; James Forrest, Ron Johnston and Michael Poulsen, 'Middle-Class Diaspora: Recent Immigration to Australia from South Africa and Zimbabwe', South African Geographical Journal 95.1 (2013): 50-69. 
majority of interviewees, causes Australians, invariably described as being aggressively monolinguistic, to feel intimidated by them. One research participant, Peter, who lost his job in 2012 and has been unemployed since then, regardless of sending out over 350 applications, said that 'you should not put on your CV that you can speak multiple languages, because you won't get the job: they'll feel intimidated and they'll know you're foreign.' ${ }^{19}$ Since South Africa's education system was of a very high standard before 1994, and since the research participants were among those who had access to it (being 'white' South Africans), they are arguably among the best-qualified immigrants Australia currently attracts. Also, Afrikaans people generally invest considerably in their children's education and they stimulate them to do well in school and get university degrees. Most interviewees experience the Australian public education standard to be shockingly low, and they therefore send their children to private schools, if they can afford it. They find that Australian society does not value tertiary education much and that the trades are seen as more important. The consequence of this perceived difference is that Australians are thought to feel even more threatened by Afrikaans immigrants, as they fear that these immigrant children will steal their children's (future) jobs. Some research participants stated that they have received literal accusations of this kind.

Once employed, whether in their own field or in another type of job, many interviewees find that they are unable to advance their career. ${ }^{20}$ Those that do bridging courses and ultimately acquire a position within their own sector, usually compete with young Australians that come fresh out of university without any strange accent. It seems that participants' South African working experience is not recognised in Australia, and therefore they start from scratch (as previously stated, going back five to ten years in career). Also, it proves to be hard for them to climb the career ladder. Most feel that this is because Australians generally dislike having immigrants as their manager/boss. In the words of Bettie, who was in a leading position for a little while, but decided to step back,

$[\ldots]$ because I found they don't tolerate other cultures as in charge of them. You can be the best worker, you can be the most appropriate person or equipped person, but because [of] your accent, I found that they

\footnotetext{
19 Peter de Keizer, conversation with author, 2015.

20 This also applies to those who did secure a job before emigrating and to 457 visa holders. It does not apply to 'expats' - those who transferred within the company they worked for - nor to university graduates recruited by multinationals.
} 
don't accept us [...] you're regarded, you're seen as criticizing, or telling them what to do, $[. .$.$] and that's why so many of our friends really strug-$ gle, 'cause they want to go into second line of management or so, and that's just unacceptable. ${ }^{21}$

Another participant, Simone, sees colleagues being promoted to positions of which she did not even know were vacant. This, combined with the fact that after two years of working at this company, still not all her colleagues talk to her, makes her believe that they are deliberately shutting her out and preventing her from advancing her career. ${ }^{22}$

\section{$3 \quad$ White Privilege and Cultural Differences}

From the above it is clear that many Afrikaans immigrants feel discriminated against by Australians in the job market. Apart from the fact that they did not anticipate this at all (based on the information they received pre-emigration), ${ }^{23}$ it seems to come as an extra shock to them, since both groups belong to the privileged 'white' peoples of our current world order. It appears that, perhaps as a consequence of the general unawareness of 'being white' (i.e. 'white privilege' ${ }^{24}$ is so normal to those who enjoy it, that they are oblivious to it), ${ }^{25}$ an unconscious expectation exists that discrimination does not occur within the 'white' group. The shock becomes clear in research participants' comments such as 'even though we are white, they misuse us'. ${ }^{26}$ A number of interviewees actually found that Afrikaans immigrants are having a harder time than those who are visibly different from Australians, such as people from the East/Asia,

\footnotetext{
21 Bettie Veenendaal, interview with author, 2015.

22 Simone Raaijmakers, interview with author, 2016.

23 It further appears that they are not warning each other/respective new Afrikaans immigrants for the anticipated difficulties. Explanations given for this are mainly cultural: to be struggling is seen as a weakness in Afrikaans culture, and therefore people often choose not to show their true feelings or express how things are really going.

24 The term 'white privilege' was famously defined by Peggy McIntosh as 'an invisible package of unearned assets that [white people] can count on cashing in each day [...]' Cited in Steve Garner, Whiteness: an Introduction (London and New York: Routledge Taylor \& Francis Group, 2007), 35-36 and can be seen as a consequence of European colonial conquest.

25 See, e.g., Garner, Whiteness, 34-39, or Ben Wadham, 'What Is Whiteness? Authenticity, Dominance, Identity', Placing Race and Localising Whiteness: Conference Proceedings for the 'Placing Race and Localising Whiteness' Conference, eds. Susanne Schech and Ben Wadham (Flinders University: Flinders Press, 2004), 22.

Laura van Oosten, interview with author, 2015.
} 
precisely because they (Afrikaans people) look exactly like them (Australians). Many stated that, in interaction with Australians, before speaking, they were treated exactly the same. However, 'the moment you open your mouth, they pick up you're not Australian, and then they go like: no, no, no, no, no'.27

It further appears that Afrikaans people do not perceive the experienced discrimination to be racially motivated (since they are 'white'), but rather as foreigner-motivated, i.e. as discrimination against immigrants in general, de facto against anyone who does not come from Anglo-Celtic heritage. They feel that white South African immigrants of British descent are not, or much less, discriminated against in Australia, since they are seen as an extension of the UK. As one interviewee stated: 'The moment you walk in with an accent that is not British or Scottish or Irish or Welsh, it's not good enough'. ${ }^{28}$ Historically, Australia has always focused on attracting immigrants from the UK, and within its long-term 'White Only Policy', British subjects were the only people that could enter Australia freely, provided that they were 'white.'. ${ }^{29}$ The definition of 'whiteness' ${ }^{30}$ was only extended on rational terms, at times when Australia saw its need to populate the country as greater than its aspiration of remaining a 'white' country (i.e. 'Populate or Perish'). ${ }^{31}$ It seems that, where in earlier times this definition was extended to the Irish, the Greeks and the Italians, currently it is being done for white South Africans. ${ }^{32}$ As one participant said: 'On the surface, their [Australians] attitude is "yes, we want immigrants here", and in their brain, they realise they have to, but in their hearts, they don't want to'.33 The 'brain' here can be symbolically seen as the Australian government or official policy, and the 'heart' as the Australian people, or the lived reality. The research participants' experiences and perceptions seem to confirm findings of previous research in this regard. According to the World Justice Project's Rule of Law

27 Rianne Hoogendijk, interview with author, 2015.

28 Laura van Oosten, interview with author, 2015.

29 James Jupp, From White Australia to Woomera: The Story of Australian Immigration (Cambridge: Cambridge University Press, 2007), 14-15.

30 As stated before, 'Whiteness' is not simply the state of having white skin. It is a social concept that may best be described as 'an everchanging, composite cultural historical construct' which, due to the history of European colonization 'has become an ideal of being the bearer of "Western" civilization [...] and as such, is a fantasy position' Ghassan Hage, White Nation: Fantasies of White Supremacy in a Multicultural Society (New York: Routledge and Annadale Nsw: Pluto Press Australia, 200o), 58.

31 See, e.g. Stratton, Uncertain Lives; Pilger, Secret Country; and Jupp, White Australia.

32 With the relatively large influx of Asian immigrants in recent times being given a status of 'honorary whiteness' Stratton, Uncertain Lives, 215.

33 Ineke van Veen, interview with author, 2015. 
Index, Australia ranks almost at the bottom when it comes to discrimination against immigrants. ${ }^{34}$ Also, despite being a 'traditional' immigration country, ${ }^{35}$ between the 1950s and the early twenty-first century, the proportion of Australians who believed that there were too many immigrants in the country has on average been about 44 per cent. ${ }^{36}$

Linked to the misleading perception that migration within the white privileged group is easy, pre-immigration, all research participants believed that Australian- and Afrikaans cultures were similar, since they are both 'Western'. Although, given the developments in South Africa since 1994, the country may no longer be regarded as 'Western', its basic economic principles are and the Afrikaans subculture is. The term broadly indicates values such as neoliberal capitalism, parliamentary democracy, individual freedom, equality, and Christianity, and refers to a common geographical descendancy from northwestern Europe.$^{37}$ However, upon arrival in Australia, nearly all research participants experienced a very real culture shock, which continues to be part of their dailylived experience, even after having stayed in Australia for many years. In reality, it appears that only those relatively superficial cultural similarities derived from the two countries' geographical locations and climatological circumstances, i.e. an outdoor lifestyle (camping, sports, barbecuing, beach life), are indeed comparable. Most interviewees define culture in terms of values however, and the deeper, underlying values and corresponding norms of Afrikaans culture are perceived to be fundamentally different from those of Australians.

To discuss the experienced cultural differences in-depth is beyond the scope of this chapter. Here, it suffices to list the four main and interrelated dichotomies that Afrikaans immigrants perceive to exist between Australian culture and their own. Most importantly, Afrikaans culture is seen as Christian, whereas Australian culture is viewed as atheist. Related to that, Afrikaans culture is thought of as valuing hard work, ambition and innovation, whereas Australian

34 Anne Susskind, 'Essential Freedoms, Yes, but Our Undertow Is Ugly', Law Society Journal: The Official Journal of the Law Society of New South Wales 48.11 (2010): 26-29, 26.

35 Hugo, 'Change and Continuity', 868.

36 Louis, et al., 'Speaking Out', 654 .

37 The values listed here are not inclusive and represent prevailing ideas about 'Westernness', which are, in line with white privilege, dictated by 'the West' and as such regarded as positive. I would argue that each of them is, to its own extent, much more a normative aspiration than a reality, except perhaps for neoliberalism. Also, to the list could arguably be added: obsessive self-control, rationality, order and the repression of emotions, which manifest themselves somatically in rigidity (see Dyer 'White' 1988, 1997 cited in Garner, Whiteness, 49), cultural gentility (see Paynter "The Cult of Whiteness in Western New England," 2001 cited in Garner, Whiteness, 49), arrogance, and, above all, hypocrisy. 
culture is perceived as consciously stimulating mediocrity. Also, whereas before emigration Afrikaans people perceived Australia, like South Africa, to be a capitalist country, in their overall experience it is much more a socialist state. Finally, Australian culture is seen as British, which is invariably described as polite, politically correct, pretentious/fake and dishonest, whereas Afrikaans culture is seen as continental European (mainly Dutch/German), which is viewed as direct, straightforward, no-nonsense/'what you see is what you get', and honest. It is important to note here that human beings generally have the tendency to view the 'in-group' as positive and the 'out-group' as negative (i.e. 'positive distinctiveness'). ${ }^{38}$ Nevertheless, the described experiences are real to the Afrikaans immigrants concerned, and the felt disconnects make their settlement process in Australia difficult. ${ }^{39}$ In fact, it is stated as one of the main reasons why many return to South Africa.

Nearly all research participants mentioned knowing families that have returned to South Africa because they could not adjust to Australian culture. For most interviewees however, returning is not an option, as they feel completely alienated from their home country, not seeing any future for their children, themselves, or for their people there. Ever since apartheid has ended, Afrikaans people have been struggling to give meaning to their lives in the new South Africa. ${ }^{40}$ It seems that, by leaving for Australia, this struggle has merely gotten extra dimensions.

\section{Bibliography}

'Afrikaanse Klub Adelaide’. Public Facebook group. Viewed 4 July 2016. https://www. facebook.com/groups/29166og6o878282/.

38 John C. Turner, 'Towards a Cognitive Redefinition of the Social Group', Social Identity and Intergroup Relations, ed. Henri Tajfel (Cambridge, London and New York: Cambridge University Press, 1982), 34 .

39 By contrast, based on their study conducted in Perth, Forrest, Johnston and Poulsen claim that white South African immigrants readily assimilate into the Australian community and labour and housing markets. Forrest, Johnston and Poulsen, 'Middle-Class Diaspora', 51, 54. Their findings are solely based on surveys, and it is not clear how many Afrikaans people were part of their study, though perhaps I will also find that Afrikaans immigrant experiences are different in Perth.

40 See, e.g. Jacob R. Boersema, 'Afrikaner, Nevertheless: Stigma, Shame, and the Sociology of Cultural Trauma' (PhD diss., University of Amsterdam, 2013); Rebecca Davies, Afrikaners in the New South Africa: Identity Politics in a Globalized Economy (London: Taurus, 2009); June Goodwin and Ben Schiff, Heart of Whiteness: Afrikaners Face Black Rule in the New South Africa (New York: Scribner, 1995). 
'Afrikaanse Klub Australië'. Viewed 4 July 2016. http://afrikaans.org.au/.

Australian Bureau of Statistics. 2016. 'Migration, Australia, 2013-14'. Australian Bureau of Statistics. Viewed 29 June 2016. http://www.abs.gov.au/ausstats/abs@.nsf/mf/ 3412.0.

Beuving, Joost, and Geert de Vries. Doing Qualitative Research: The Craft of Naturalistic Inquiry. Amsterdam: Amsterdam University Press, 2015.

Birrel, Bob, and Ernest Healy. 'The Impact of Recent Immigration on the Australian Workforce'. Centre for Population and Urban Research, February 2013. Viewed 12 March 2016. http://tapri.org.au/wp-content/uploads/2016/o2/birrell-healy-feb-2013.pdf.

Bhugra, Dinesh, and Matthew A. Becker. 'Migration, Cultural Bereavement and Cultural Identity'. World Psychiatry 4.1 (2005): 18-24.

Boersema, Jacob R. 'Afrikaner, Nevertheless: Stigma, Shame, and the Sociology of Cultural Trauma'. PhD Dissertation, University of Amsterdam, 2013.

Bornman, Elirea. 'Emigrasie onder Afrikaners vandag'. Tydskrif vir Geesteswetenskappe 45.3 (2005): 386-399.

Brown, Rick. 'The Dynamics of Australia's Immigration Policy'. People and Place 16.1 (2008): 55-58.

Cai, Lixin and Amy Y.C. Liu. 'Wage Differentials between Immigrants and the NativeBorn in Australia'. International Journal of Manpower 36.3 (2015): 374-396.

'Census 2011'. Australian Bureau of Statistics. Viewed 29 June 2016. http://www.abs.gov .au/census.

Davies, Rebecca. Afrikaners in the New South Africa: Identity Politics in a Globalized Economy. London: Taurus, 2009.

Forrest, James, Ron Johnston and Michael Poulsen. 'Middle-Class Diaspora: Recent Immigration to Australia from South Africa and Zimbabwe'. South African Geographical Journal 95.1 (2013): 50-69.

Garner, Steve. Whiteness: An Introduction. London and New York: Routledge Taylor \& Francis Group, 2007.

Giliomee, Hermann. 'The Afrikaners: Twenty Traumatic Years'. Adapted version of an article that first appeared in Beeld newspaper, 1 March 2010. Viewed 30 June 2015. http://www.politicsweb.co.za/news-and-analysis/the-afrikaners-twenty-traumatic -years.

Giliomee, Hermann. The Afrikaners: Biography of a People. London: Hurst \& Company, 2011.

Goodwin, June and Ben Schiff. Heart of Whiteness: Afrikaners Face Black Rule in the New South Africa. New York: Scribner, 1995.

Government of Australia, 2016, 'Temporary Work (Skilled) Visa (Subclass 457)'. Government of Australia, Department of Immigration and Border Protection. Viewed 14 May 2016. https://www.border.gov.au/Trav/Visa-1/457-. 
Government of Australia. 2016. 'Skilled Nominated Visa'. Government of Australia, Department of Immigration and Border Protection. Viewed 14 May 2016. https://www .border.gov.au/Trav/Visa-1/19o-.

Hage, Ghassan. White Nation: Fantasies of White Supremacy in a Multicultural Society. New York: Routledge and Annadale nsw: Pluto Press Australia, 2000.

Hatoss, Anikó, Donna Starks and Henriette Janse van Rensburg. 'Afrikaans Language Maintenance in Australia'. Australian Review of Applied Linguistics 34.1 (2011): 4-23.

Hemer, Susan. 'Grief as Social Experience: Death and Bereavement in Lihir, Papua New Guinea'. Australian Anthropological Society 21 (2010): 281-297.

Hugo, Graeme. 'Change and Continuity in Australian International Migration Policy'. International Migration Review 48.3 (2014): 868-89o.

'Immigration SA'. Government of South Australia. Viewed 10 April 2016. http://www .migration.sa.gov.au

Jupp, James. From White Australia to Woomera: The Story of Australian Immigration. Cambridge: Cambridge University Press, 2007.

Louis, Winnifred R., Julie M. Duck, Deborah J. Terry, and Richard N. Lalonde, 'Speaking Out on Immigration Policy in Australia: Identity Threat and the Interplay of Own Opinion and Public Opinion'. Journal of Social Issues 66.4 (2010): 653-672.

Louw, Eric, and Gary Mersham. 'Packing for Perth: The Growth of a Southern African Diaspora'. Asian and Pacific Migration Journal 10.2 (2001): 303-333.

Lucas, David, Acheampong Yaw Amoateng and Ishmael Kalule-Sabiti. 'International Migration and the Rainbow Nation'. Population, Space and Place 12 (2006): 45-63.

Pilger, John. A Secret Country: The Hidden Australia. New York: Alfred A. Knopf, Inc., 1991.

Stratton, Jon. Uncertain Lives: Culture, Race and Neoliberalism in Australia. Newcastle upon Tyne: Cambridge Scholars Publishing, 2011.

Sloan, Judith. 'Migrants No Threat to Jobs'. The Australian, 26 August 2014. Viewed 12 March 2016. http://www.theaustralian.com.au/opinion/columnists/judith-sloan/ migrants-no-threat-to-jobs/news-story/824de67ao2c4f3co2694bf3791555aof.

Sonn, Christopher, Gavin Ivey, Alison Baker, and Kirsten Meyer. 'Post-Apartheid South African Immigrants in Australia: Negotiating Displacement, Identity and Belonging. Qualitative Psychology Advance online publication, 2015. Viewed 3 March 2016. http://dx.doi.org/10.1037/qupooooo39.

'South Africans in Adelaide'. Public Facebook group. Viewed 4 July 2016.

https://www.facebook.com/groups/2443719340/.

Statistics South Africa. 2012. 'Mid-Year Population Estimates 2011'. Viewed 7 March 2012. http://www.statssa.gov.za/publications/Po3O2/Po3O22011.pdf.

Susskind, Anne. 'Essential Freedoms, Yes, But Our Undertow Is Ugly'. Law Society Journal: The Official Journal of the Law Society of New South Wales 48.11 (2010): 26-29. 
Turner, John C. 'Towards a Cognitive Redefinition of the Social Group'. Social Identity and Intergroup Relations, edited by Henri Tajfel, 15-40. Cambridge, London and New York: Cambridge University Press, 1982.

Van Rooyen, Johann. The New Great Trek: The Story of South Africa's White Exodus. Pretoria: Unisa Press, 2000.

Visser, Bruce. 'From "Braai" to Barbecue: South African Immigration to Australia'. PhD Dissertation, Flinders University, 2004.

Visser, Wessel. 'Afrikaner Responses to Post-Apartheid South Africa: Diaspora and the Re-Negotiation of a Cultural Identity'. New Contree 54 (2007): 1-30.

Wadham, Ben. 'What Is Whiteness? Authenticity, Dominance, Identity'. Placing Race and Localising Whiteness: Conference Proceedings for the 'Placing Race and Localising Whiteness' Conference, edited by Susanne Schech and Ben Wadham, 19-27. Flinders University: Flinders Press, 2004. 